\title{
Application of Emotional Teaching Method in English Teaching in Vocational Colleges
}

\author{
Xiangmin $\mathrm{Li}$ \\ Foreign Language Department of Luohe Vocational Technology Colledge, 462000
}

Keywords: Emotional teaching method; Vocational colleges; English teaching

\begin{abstract}
Emotional teaching method means that when teachers guide students to read and analyze English texts, they can make students feel and comprehend the affective factors contained in the texts. When teaching, teachers hope to reach emotional resonance and emotional feedback with students. Based on the emotional teaching, forming the individual character of English learning can enhance the moral ability, improve the ability of listening, speaking, reading and writing, and promote the development of academic intelligence. In the process of English teaching in vocational colleges, emphasizing emotional teaching, we can summarize the interactive methods in teaching practice. This is the process of the in-depth development of quality education and the reform of the new curriculum. It is an important realistic meaning to realize English teaching in vocational colleges with a new perspective and mode.
\end{abstract}

\section{Introduction}

Vocational education is one of the most important educational contents in the educational environment of our country. With the development of economy and society, learning accurate handicraft skill is the change of people's professional concept. Choosing vocational and technical education and learning a skill become selections of a lot of students. With the expansion of vocational education and the development of students' structure, although many students have obviously improved their cultural literacy, accumulation of English knowledge is still relatively scarce because students in vocational colleges generally have a poor education of English. Therefore, it is necessary to strengthen the improvement of tools and modes of English teaching and meet the severe challenges of English teaching in vocational education through the method of emotional teaching. This paper analyzes and studies a series of contents on practice teaching of emotional teaching.

\section{The Important Role of Emotional Teaching Method in Vocational Colleges Teaching}

\section{Emotional teaching can build a better teacher-student relationship}

In the process of English teaching in vocational colleges, every word and deed of teachers will reflect their English literacy. Teachers and students can achieve effective teacher-student relationship through good communication. Such relationship between teachers and students is an emotional experience in itself. A good relationship between teachers and students will help teachers to pour a lot of knowledge into the minds of students, which makes students absorb the knowledge like sponges and work hard to improve their English learning ability. This is a process of formation of positive enthusiasm. Teachers fully understand the personality and psychology of students, and then they can be targeted to pay attention to students' English learning. Teaching students in accordance with their aptitudes and solving some problems in the interaction between teachers and students through active communication, teachers can work hard to put their energies into the vocational English education, and lay good foundation for students' learning.

\section{Emotional education can reflect the concern to students}

Emotional education is a teacher's love for students, but also a bridge between mutual concern between students and teachers. Through the factors of emotional education, teachers can grasp more flexible teaching materials and pay more attention to students. The so-called teaching student in accordance of their aptitude is based on concern and understanding of teachers on students. 
Teachers pay attention to cultivating emotional relations with students and can exert the positive factors of emotional education. English teachers of vocational and technical colleges grasp the factors such as teaching materials center, starting from the concern to students. Through the full expression of emotional expression and infection, teachers form a good habit of learning English, feel the thirst for knowledge of students, infect students with emotional education, and assist students' psychological changes so as to imperceptibly enhance interest of students in English learning. Concern is on both sides. The teacher's concern for students is reflected in experiencing and observing students' psychology, so as to develop and implement targeted teaching methods; under the teacher's attention, students will follow the teacher's teaching plan step by step of focused English learning, from speaking, writing to words, grammar, and comprehensively improve their overall quality of English.

\section{Application of Emotional Teaching Method in English Teaching in Vocational Colleges}

The method of emotional education is not uncommon in the process of English teaching in vocational colleges. It can reasonably use the method of emotional education to arouse the mutual trust between English teachers and students, which is quite important to build efficient classroom.

The connotation of emotion makes the students resonate with the knowledge of textbooks

English teaching materials are the footholds in English learning process of students in vocational colleges. In the course of teaching instruction, English teachers in vocational colleges will sort out the knowledge points of teaching materials effectively and process the teaching materials so that the contents of teaching materials and teachers' emotions can be organically linked together, which can fully play the role of emotional education and value. English teachers in vocational colleges can understand the affective factors in the textbooks well, and through active exploration and rational arrangement, they can implement true feelings in the process of emotional teaching. The selected contents in textbooks are often very classical, and close to the daily life of students, with emotion to infect students. It can make the students have a positive resonance with the knowledge in the teaching materials, and can deepen the impression of the important knowledge of the English teaching materials.

\section{Emotional expression can stimulate the English teacher's teaching with true feelings}

Emotional expression can inspire full of true feelings of teachers, and only teaching on the basis of true feeling, can teachers effectively infect the students' psychology so that students feel the subtle influence of English brought by the baptism of the soul. In fact, English itself is a common language for human civilization to communicate with each other. Vocational teaching and English literature also permeate the emotions of English-speaking people. Therefore, the expression of emotion can stimulate the true feelings of English teachers. This is reflected in the process of English teaching in some practical teaching ideas, the actual teaching content, as well as understanding and application of extra-curricular supplementary teaching material, understanding and application. The teachers learn the knowledge point of the textbook, and are inspired by the spirit of the protagonist in the textbook article, and they may guide students of vocational colleges in the English teaching process to influence the formation of values and outlook on life with more teaching contents and teaching materials. Simple values permeate the learning of English teaching. Using the learning materials to understand the emotional experiences of the international people can stimulate teachers' emotions and can affect students, which will deeply influence all kinds of ideas and thinking model formed around English learning in the interaction between teachers and students.

\section{Emotional teaching can promote teachers and students to excavate the stories of teaching materials}

Emotional teaching will stimulate people's learning curiosity and learning morale and stimulate students to learn more about the contents of the story. Many textbooks in the choice of the content take into account the interest of students learning and the forming process of various values. Therefore, the excavation of teaching materials and the learning of extending content will be very good to stimulate students' interest in learning. The method of emotional teaching can promote the 
mutual excavation of teaching materials for teachers and students. Reasonably using the emotional education method can eliminate the negative emotions of the students for teaching material learning and improve the comprehensive learning effect of the students in vocational colleges in English learning ability. If teachers themselves have a strong interest in learning English, and spread this interest to students, they can excavate more stories and aspects behind English learning with the method of learning together. At the same time, many English teachers and colleges may open entirely new teaching books in the process of vocational education. And the development and study of these college-based teaching materials infiltrate teachers' strong emotions, which may be more likely to be infected and triggered students' learning enthusiasm during the course of explaining college-based teaching materials.

\section{Emotional teaching can make students better involve in English social practice}

English is a tool for social practice. Emotional teaching can help students better integrate themselves into English social practice. This is because having a better ability of listening, speaking, reading and writing in the process of English learning will help to promote the use of knowledge acquired by students in vocational colleges and it is also beneficial to achieve the purpose of learning in the process of knowledge application. If students have a better ability to learn English in the process of social practice, they can work and have emotional exchanges with foreign friends. Therefore, in the process of social practice, students will constantly like English due to the improvement of English learning ability, thus promoting habit formation of self-lifelong learning English. Teaching method with emotional penetration helps students better engage in English practice, and can help students understand all the problems in the learning process, develop a scientific and effective solution, and experience the test of practice to avoid students' over-confusion situation in English learning and in the process of practice. Allowing students to better integrate English media and English media-based society in the process of teaching English, students' positive emotional experience can lead them to break the waves and break down negative and negative emotions to actively meet the challenges of English learning in all aspects after the test of time and practice.

\section{The key Points of Emotional Teaching in English Teaching in Vocational Colleges}

The key points of emotional teaching method in the process of English teaching in vocational colleges are mainly reflected in the use of emotion to eliminate students' fear of learning English. At the same time, emotional teaching method can help English teachers to respect students' individual learning, and deeply dig a series of difficult problems in the practice of English teaching and help students show more positive attitude in the future application of English learning. English learning itself is based on the values and habits of English-speaking countries. Therefore, students are hoped to gradually learn the process of self-learning in English learning based on a better understanding of the ideas and habits of thinking of English native speakers. Therefore, emotional teaching method should focus on the expression of this emotion in English teaching of vocational colleges.

\section{Using emotional teaching to eliminate students' fear of English}

The use of English emotional teaching method can help English teachers to actively change students' fear of English learning through teaching methods of love and encouragement. This is because many students in vocational colleges have a headache in learning English because of their weak English foundation, and in the process of learning, they may fear of English learning due to various problems. Therefore, teachers should effectively eliminate students' fear of learning English in the teaching process. They should start from the foundation and should not request too high of students' records and degrees. Teachers should teach students in accordance of their aptitude and step by step and understand the shortcomings in the process of learning English, meanwhile help students to establish the planning of English learning. Consequently, through daily study and education, they help students master the practical difficulty and level of professional English with the fastest way.

For instance, 


\section{[Analysis of teaching material]}

The learning content is mainly reflected in the following three points:

Learning words about personal characters: tall, thin, short, heavy, calm, wild, long hair, short hair, outgoing, quiet, funny, serious, smart, athletic, etc.

Learning the important sentence patterns of personal comparative:

Pedro is funnier than Paul. (2) Tina is taller than Tara. (3) Tom is more athletic than Sam.

Grasp the grammar point: the comparative and superlative degrees of adjectives (The comparative and superlative of adjectives)

Teaching process:

Teachers can organize students to study in the form of drama, and make students choose their favorite combination of playmates according to students' personality traits, appearance features to flexibly build dialogue. Teachers can ask students to use English knowledge to describe each other's characteristics, and also imitate the book dialogue on the situation so that students can feel the emotions of the words in the funny scenario in classroom, thus to better grasp English emotion when using.

In this process of emotion education, teachers should pay attention to effectively infusing love and encouragement into the process of emotion teaching. Teachers should not only grasp the emotion in English texts and reading materials, but also grasp the interest that can effectively stimulate students' learning, and it is the highest level of English emotional teaching that students can understand the emotion expressed in the English learning materials and feel the teacher's concern and love for the students.

\section{Emotional Teaching Helps English Teachers Respect Students' Individuality}

Emotional teaching methods can help English teachers to teach on the basis of respecting the individuality of students. English itself is a language of "gentleman". Grammar has its own unique cultural contents. Using different combinations of common expressions all permeate this concept of respect and equality. Therefore, in the process of communication and learning, teachers should not only regard English teaching as the content of textbooks, but should regard the teaching of emotions as a way of daily teaching practice in classroom communication and imperceptibly penetrate the emotion education. In life and classroom practice, extensive use of English teaching can help teachers of English teaching develop personalized English learning programs and goals according to the characteristics of students, and in the process of learning English, students strictly follow the established plan, which will gradually enhance the confidence of learning English. The concept of equality is demanded to respect the personality of students and respect the students. Under the new era, the breakthrough development of the relationship among people should be focused. Under the guidance of cognitive theory and construction theory, even if students have some specific problems in the process of English learning and application, teachers can also help students slowly give up the psychological burden through the process of emotional teaching and mutual exchange. In the process of emotional teaching, there may be some short-term regression or fluctuations. Students in vocational colleges may fluctuate due to some emotions or impact of various values because they are in the learning process of the youth stage. Teachers should closely observe the possible change and reason of the students during the learning process, and make the best use of circumstances to help students find the starting point of English learning from the point of view most concerned by the students, thus to help them eliminate the fluctuation of negative emotions and meet the challenges of learning with a positive attitude.

For instance,

[Learning objectives]

Knowledge objectives: Students can correctly listen, speak, read and write the lexical phrases such as China, Chinese, England, America, and English. Use "I want to" to express own thoughts.

Skills objectives: Familiar with the general situation of Anglo-American countries; Familiar with Anglo-American culture.

Emotional aims: loving English, improving interest in learning English.

[Learning focus]: Emphatically mastering the usage of think and thinker. 
[Learning difficulties]: usage of roots and affixes, such as the meaning of noun suffix “-er".

It is the focus of this lesson to help students build longer-term learning goals, love English, and improve their English learning based on an overview of Anglo-American countries.

\section{Conclusion}

For the English emotional teaching, in the process of vocational education and teaching, teachers should pay attention to the emotional roles. Using English teaching and research methods to effectively improve the quality and efficiency of English teaching can make the majority of vocational college students have higher literacy English ability, which can lay a good foundation for their future work or living in the English environment. English learning itself is the process of developing lifelong learning habits. The whole process of creating English learning based on emotional education can affect students' love of English in the future so that they can learn endlessly.

\section{Reference}

[1] Yao Y.: Application of emotional teaching method in English class in vocational colleges [J]. Modern Vocational Education, 2017, (16): 117. In Chinese.

[2] Li L.R.: Application of situational teaching method in English teaching in vocational colleges [J]. Campus English, 2017, (10): 58. In Chinese.

[3] Zheng X.S.: Application analysis of emotional teaching in English teaching in vocational colleges [J]. Bosom Friend Inspiration, 2016, (20): 184. In Chinese.

[4] Xu W.: Application of emotional teaching in vocational college English teaching [J]. Course Education Research, 2016, (29): 97-98. In Chinese.

[5] Xie L.F.: Accurate application of emotional teaching method in English classroom teaching in vocational colleges [J]. Labor Security World, 2016, (17): 75+77. In Chinese.

[6] Hao J.: Emotional education based on English teaching in vocational colleges [J]. The Modern Occupation Education, 2015, (05): 57-58. In Chinese.

[7] Li Y.Q.: Situational teaching method in secondary vocational English oral teaching application [D]. Hebei Normal University, 2014. In Chinese.

[8] Yang X.: Application of emotional teaching method in mechanical basic teaching [J]. Science \& Technology Vision, 2014, (20): 245+256. In Chinese.

[9] Yuan X.W.: Application of emotional teaching in college English classroom teaching [D]. Jilin University, 2014. In Chinese.

[10] Jin L.Z.: Study and application of emotional factors in English teaching in secondary vocational colleges [J]. Success (Education), 2011, (11): 145. In Chinese.

[11]Xin M.M.: Situational teaching method in the English classroom teaching of higher vocational colleges [D]. Shandong Normal University, 2011. In Chinese.

[12] Shi Z.Y.: Application of situational teaching method in higher vocational colleges [J]. Lanzhou Academic Journal, 2008, (S2): 167-168. In Chinese. 